\title{
SIGHTINGS OF HUMPBACK WHALES ON THE VITÓRIA-TRINDADE CHAIN AND AROUND TRINDADE ISLAND, BRAZIL
}

\author{
Salvatore Siciliano ${ }^{I}$, Jailson F. de Moura ${ }^{I}$, Henrique R. Filgueiras ${ }^{2}$, \\ Paulo P. Rodrigues ${ }^{3}$ and Nilamon de Oliveira Leite $\mathrm{Jr}^{4}$
}

${ }^{1}$ Grupo de Estudos de Mamíferos Marinhos da Região dos Lagos (GEMM-Lagos), Departamento de Endemias Samuel Pessoa, Escola Nacionalde Saúde Pública/FIOCRUZ. Rua Leopoldo Bulhões, 1.480 -6². andar, sala 620, Manguinhos-21041-210, Rio de Janeiro, RJ, Brazil.

${ }^{2}$ Reserva Biológica de Comboios/Projeto Tamar, Caixa Postal 105, 29900-970 - Regência, Linhares, ES Brazil

${ }^{3}$ Instituto Ecomaris, Rua Renato Nascimento Daher Carneiro, 780.Condomínio Village, Edifício Delacroix, apto 203. Ilha do Boi - 29052-730 Vitória, ES, Brazil.

${ }^{4}$ Projeto Tamar/ICMBio, Av. Paulino Müller, 1111, Jucutuquara - 29040-715 Vitória, ES, Brazil

*Corresponding Author: sotaliaworkshop@gmail.com

Descriptors: Megaptera novaeangliae, Trindade Island; Brazil, Sightings, Migration. Descritores: Megaptera novaeangliae, Ilha de Trindade, Brasil, Avistagem, Migração.

The Trindade and Martim Vaz islands belong to an archipelago located $1,140 \mathrm{~km}$ east of Vitória, Espírito Santo State, Brazil, in the Southern Atlantic Ocean. The archipelago consists of six islands of which Trindade $\left(20^{\circ} 30^{\prime} \mathrm{S}\right.$ and $\left.29^{\circ} 18^{\prime} \mathrm{W}\right)$, with an area of $10.1 \mathrm{~km}^{2}$, is the largest and Martim Vaz, with an area of $0.3 \mathrm{~km}^{2}$, the second in size. The archipelago has a total area of $10.4 \mathrm{~km}^{2}$ (4.0 sq mi). Its isolation on the ocean surface makes it difficult to perceive that it is part of the Vitória-Trindade Alignment, a great E-W submarine volcanic chain. The volcano lies on the ocean floor at a depth of about 5,500 m. Other volcanic constructions belonging to this alignment between Trindade-Martim Vaz and the coast have been completely eroded by the sea, and leveled down to $100 \mathrm{~m}$ depth. They are the guyots, usually called banks, but the islands, probably due to prolonged volcanic activity, are still high above the ocean surface. The Trindade island platform has a limited area, the width varying between 800 and $3,000 \mathrm{~m}$ (ALMEIDA, 2002).

In the Southwest Atlantic Ocean the winter breeding ground of $M$. novaeangliae is located on the north-eastern coast of Brazil, on the Abrolhos Bank $\left(16^{\circ} 55^{\prime} \mathrm{S}, 38^{\circ} 50^{\prime} \mathrm{W}\right)$ and in its surroundings (ZERBINI et al., 2004). The Abrolhos Bank, with its shallow (0$50 \mathrm{~m})$, warm waters $\left(23^{\circ} \mathrm{C}\right)$ protected from the prevailing $\mathrm{NE}$ winds and covered with coral communities, provides an ideal breeding habitat for humpback whales (SICILIANO, 1995). Studies conducted in the Abrolhos breeding ground, northeastern Brazil, indicate that humpbacks inhabit that region from June to January, with peaks between August and October (MARTINS et al., 2001).
Antarctic feeding activity extends from November to at least April (STONE; HAMMER, 1988; SECCHI et al., 2001). Additionally, occasional sightings have been reported in the Fernando de Noronha Archipelago $\left(\sim 3^{\circ} \mathrm{S}\right)$ and off southern and south-eastern Brazil (e.g. LODI, 1994; PIZZORNO et al., 1998). Siciliano (S. Siciliano, pers. comm.) reported 16 sightings of humpback whales off Trindade Is. and in the surrounding area between 1984 and 1994. The group composition of the whales sighted by this author included: singletons, mother-calf, mother-calf and escort and trios. Further, the possibility of the Trindade and Martin Vaz archipelago being one of the destinations of humpback whales wintering off Brazil was discussed.

In this note we report on two sets of opportunistic sightings of humpback whales off the south-east coast of Brazil between 2003 and 2007. Sightings were made onboard a longline fishing boat operating along the Vitória-Trindade Chain from 27 October to 10 November 2003. A second set of sightings was collected during a trip to Trindade Is. from July to August 2007. Observations of humpback whale groups during 2007 were made from cliff-top vantage points on the mainland. Whenever possible, a description of the general behavior of the whales was recorded ad libitum.

Twelve sightings of groups of humpback whales were made during the longline fishing trip carried out in 2003 along the Vitória-Trindade chain (Fig. 1; Table 1). It is suggested that the region may be an important migratory corridor for $M$. novaeangliae to use the Abrolhos archipelago as a breeding ground. On the other hand, previous studies have also 
suggested that the humpback population that breeds in Brazilian waters has increased in recent decades and the area used to breed has expanded as well (FREITAS et al., 2004; ANDRIOLO et al., 2006; ROSSI-SANTOS et al., 2008).

During one of the 2003 voyages whale groups were twice observed moving across an immersed longline fishery operation. Whales may become entangled in this fishing gear, commonly used in the Vitória-Trindade chain, as has been observed elsewhere in the world (CASSOFF et al., 2011).

Seven sightings of humpback groups were recorded in July-August 2007 near Trindade Is. by observation from the mainland. Additionally, previous data from S $(1997 ; n=16)$ and Townsend $(1935 ; n=01)$ were considered in this work for the spatial and group composition analysis (Fig. 1, Table 1). A total of 24 sightings of whale groups were recorded around Trindade Is. Mother-calf pairs were sighted on five different occasions, representing $20.8 \%$ of the all the recordings made of whales' group around the Island, (excluding the 2003 sightings on the VitóriaTrindade chain). New projects are needed to study the habitat use, group composition and behavior of the whales that visit this oceanic region. The sightings around Trindade Is. were of solitary individuals or pairs. Aerial behavior such as pectoral fin waving, tail slapping, and breaching were observed during seven of the sightings.

Townsend's (1935) classic whale charts, which illustrate where American open-boat (premodern) whalers took sperm, humpback, right and bowhead whales worldwide, evidence few catches of humpback whales off Trindade. Reports of humpback whales relating to 1984,1993 and 1994 were the first evidence of the presence of the species off Trindade in recent decades (Siciliano, pers. comm.). This author also discussed the probable origin of these whales and their connection with other major breeding grounds.

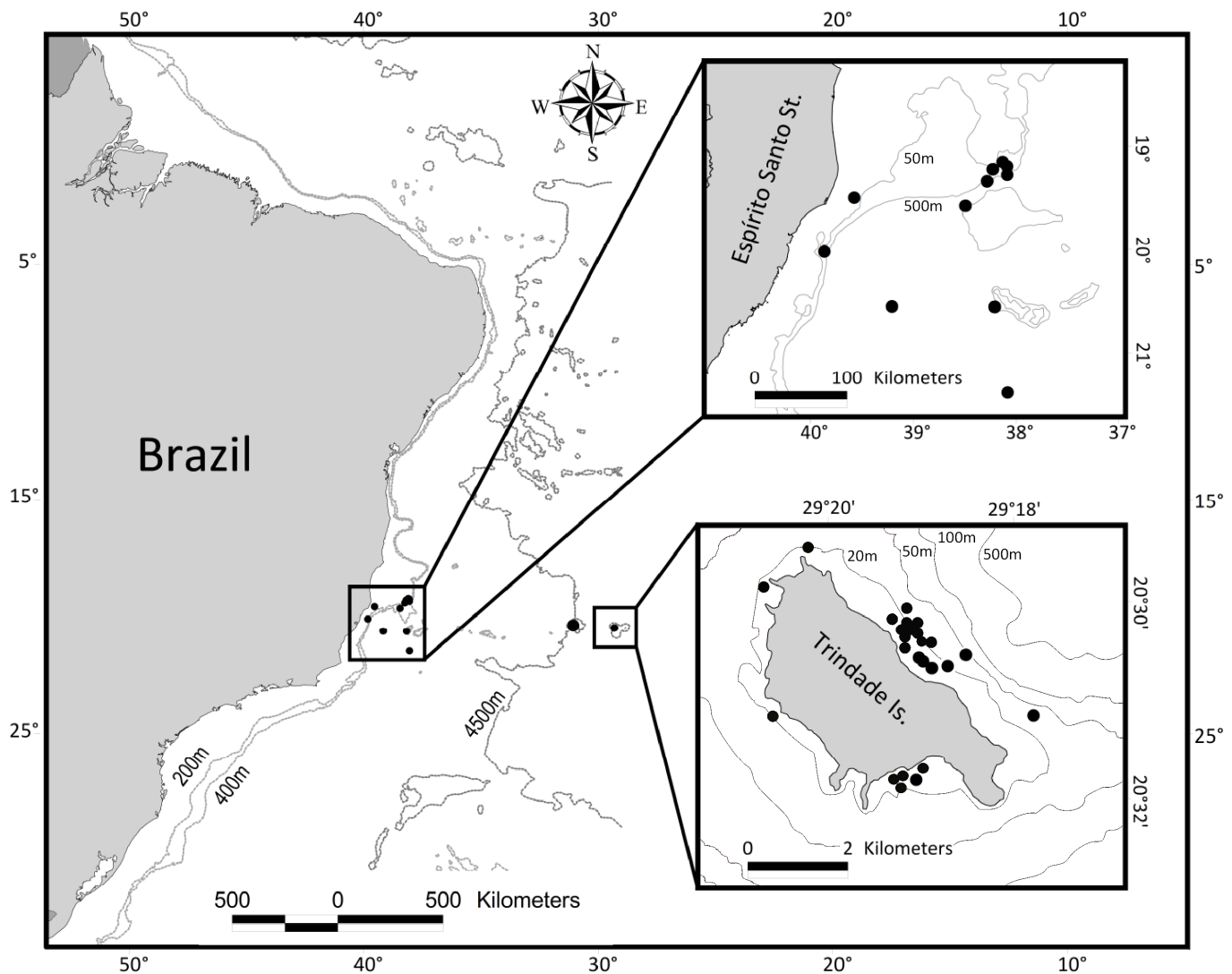

Fig. 1. Sightings of humpback whale groups during a longline fishing trip along VitóriaTrindade chain (2003) and around Trindade Island (2007), Brazil. 
Table 1. The table also shows previously published sightings around Trindade Island provided by Siciliano (S. Siciliano, unpublished data)* and Townsend (1939)\#.

\begin{tabular}{|c|c|c|c|}
\hline DATE & LATITUDE & LONGITUDE & OBSERVATIONS \\
\hline XIX Century ${ }^{\#}$ & $20^{\circ} 30^{\prime}$ & $29^{\circ} 19^{\prime}$ & $\begin{array}{l}\text { At least two humpbacks caught by U.S. Whalers } \\
\text { (TOWNSEND, 1939) }\end{array}$ \\
\hline 19 August $1984 *$ & $20^{\circ} 30^{\prime}$ & $29^{\circ} 19^{\prime}$ & Mother-calf and escort swimming \\
\hline 15 August $1993 *$ & $20^{\circ} 30^{\prime}$ & $29^{\circ} 19^{\prime}$ & Three humpback whales, southward bound, in aerial behavior \\
\hline 09 August 1994* & $20^{\circ} 30^{\prime}$ & $29^{\circ} 19^{\prime}$ & Two whales swimming northeastwards \\
\hline 09 August $1994 *$ & $20^{\circ} 30^{\prime}$ & $29^{\circ} 19^{\prime}$ & Two whales swimming northeastwards \\
\hline 11 August $1994 *$ & $20^{\circ} 31^{\prime}$ & $29^{\circ} 19^{\prime}$ & Two whales swimming southwards \\
\hline 16 August $1994 *$ & $20^{\circ} 31^{\prime}$ & $29^{\circ} 19^{\prime}$ & $\begin{array}{l}\text { Three humpback whales moving southwards: breaching, } \\
\text { leaping from the water or slapping their tail flippers on the } \\
\text { surface }\end{array}$ \\
\hline 18 August $1994 *$ & $20^{\circ} 31^{\prime}$ & $29^{\circ} 19^{\prime}$ & Mother-calf pair swimming eastwards \\
\hline 18 August $1994 *$ & $20^{\circ} 31^{\prime}$ & $29^{\circ} 19^{\prime}$ & A whale in intense aerial behavior moving southwards \\
\hline 19 August $1994 *$ & $20^{\circ} 29^{\prime}$ & $29^{\circ} 19^{\prime}$ & One humpback travelling southwards \\
\hline 22 August 1994* & $20^{\circ} 30^{\prime}$ & $29^{\circ} 19^{\prime}$ & Mother-calf pair in aerial behavior swimming northeastwards \\
\hline 23 August $1994 *$ & $20^{\circ} 30^{\prime}$ & $29^{\circ} 19^{\prime}$ & Mother-calf pair in aerial behavior swimming northeastwards \\
\hline 01 September $1994^{*}$ & $20^{\circ} 30^{\prime}$ & $29^{\circ} 19^{\prime}$ & $\begin{array}{l}\text { Two humpback whales showing their flipper above the } \\
\text { water. Moving northeastwards }\end{array}$ \\
\hline 10 September $1994 *$ & $20^{\circ} 28^{\prime}$ & $29^{\circ} 20^{\prime}$ & Mother-calf pair in aerial behavior swimming northeastwards \\
\hline 17 September $1994 *$ & $20^{\circ} 31^{\prime}$ & $29^{\circ} 20^{\prime}$ & Two whales moving southeastwards \\
\hline 08 October $1994 *$ & $20^{\circ} 30^{\prime}$ & $29^{\circ} 19^{\prime}$ & Two whales moving northeastwards \\
\hline 08 October $1994 *$ & $20^{\circ} 30^{\prime}$ & $29^{\circ} 19^{\prime}$ & Two whales moving northeastwards \\
\hline July 2007 & $20^{\circ} 30^{\prime}$ & $29^{\circ} 19^{\prime}$ & $\begin{array}{l}\text { Two humpback whales moving southeastwards: breaching, } \\
\text { leaping from the water or slapping their tail flippers on the } \\
\text { surface }\end{array}$ \\
\hline July 2007 & $20^{\circ} 30^{\prime}$ & $29^{\circ} 18^{\prime}$ & $\begin{array}{l}\text { Two humpback whales moving southeastwards: breaching, } \\
\text { leaping from the water or slapping their tail flippers on the } \\
\text { surface }\end{array}$ \\
\hline July 2007 & $20^{\circ} 30^{\prime}$ & $29^{\circ} 18^{\prime}$ & $\begin{array}{l}\text { Two humpback whales moving southeastwards: breaching, } \\
\text { leaping from the water or slapping their tail flippers on the } \\
\text { surface }\end{array}$ \\
\hline July 2007 & $20^{\circ} 30^{\prime}$ & $29^{\circ} 18^{\prime}$ & One humpback whale moving northwards \\
\hline August 2007 & $20^{\circ} 30^{\prime}$ & $29^{\circ} 18^{\prime}$ & Two humpback whales travelling northeastwards \\
\hline August 2007 & $20^{\circ} 30^{\prime}$ & $29^{\circ} 17^{\prime}$ & Two humpback whales travelling northeastwards \\
\hline August 2007 & $20^{\circ} 31^{\prime}$ & $29^{\circ} 19^{\prime}$ & Humpback whales in aerial behavior \\
\hline 27 October 2003 & $20^{\circ} 39^{\prime}$ & $39^{\circ} 09^{\prime}$ & Mother-calf pair swimming \\
\hline 27 October 2003 & $20^{\circ} 39^{\prime}$ & $38^{\circ} 09^{\prime}$ & Group of humpback whales travelling southwards \\
\hline 28 October 2003 & $20^{\circ} 28^{\prime}$ & $31^{\circ} 03^{\prime}$ & Four humpback whales travelling \\
\hline 29 October 2003 & $21^{\circ} 29^{\prime}$ & $38^{\circ} 02^{\prime}$ & Humpback whale milling \\
\hline 01 November 2003 & $19^{\circ} 17^{\prime}$ & $38^{\circ} 02^{\prime}$ & Mother-calf pair travelling southwards \\
\hline 02 November 2003 & $19^{\circ} 40^{\prime}$ & $38^{\circ} 27^{\prime}$ & Humpback whales swimming across long line fishing gear \\
\hline 02 November 2003 & $29^{\circ} 25^{\prime}$ & $38^{\circ} 14^{\prime}$ & Humpback whale blowing \\
\hline 05 November 2003 & $19^{\circ} 22^{\prime}$ & $38^{\circ} 02^{\prime}$ & $\begin{array}{l}\text { Humpback whales in aerial behavior: breaching, leaping } \\
\text { from the water or slapping their tail flippers on the surface }\end{array}$ \\
\hline 05 November 2003 & $19^{\circ} 14^{\prime}$ & $38^{\circ} 05^{\prime}$ & Humpback whale blowing \\
\hline 08 November 2003 & $19^{\circ} 18^{\prime}$ & $38^{\circ} 11^{\prime}$ & Up to 3 groups of humpback whales \\
\hline 09 November 2003 & $19^{\circ} 35^{\prime}$ & $39^{\circ} 32^{\prime}$ & Humpback whale blowing \\
\hline 10 November 2003 & $20^{\circ} 07^{\prime}$ & $39^{\circ} 49^{\prime}$ & $\begin{array}{l}\text { Group of six humpback whales swimming across longline } \\
\text { fishing gear }\end{array}$ \\
\hline
\end{tabular}

Pre-modern whaling data for South American waters $(1831 / 32)$ indicate that humpback whales were observed in the same seasonal period and migratory route locations recognized at the present time in Brazil (BEST, 2008). According to Best (2008) the whales observed 500 to 1,000 nautical miles off the Brazilian coast (including sightings off Trindade Is.) between latitudes 17 and $28^{\circ} \mathrm{S}$ in midwinter suggest that the destination of these cetaceans may not be the Abrolhos bank (18 $\left.30^{\prime} \mathrm{S}, 39^{\circ} 30^{\prime} \mathrm{W}\right)$, but a region further north and east. Humpback whales are relatively abundant on the north-eastern Brazilian coast, far north of the Abrolhos bank and where important whaling activities occurred in the 20th century (ZERBINI et al., 2004; ANDRIOLO et al., 2010). According to Zerbini et al. (2004), the high density of whales off northeastern Brazil suggests that the species is undergoing a process of reoccupation of 
a historical area of distribution, and the presence of newborn individuals indicates that calving and nursing occur in the area. Data on telemetry presented by Zerbini et al. (2011) show a female M. novaeangliae tagged off Brazil (far north of the Abrolhos bank) migrating southward over the Vitória-Trindade submarine chain (at a point $200 \mathrm{~km}$ from Trindade Is.) towards the South Sandwich Archipelago. It is common for oceanic islands (such as Trindade and Martim Vaz) to serve as habitats for humpback whales during their migrations, as is seen in the Pacific Ocean (HAUSER et al., 2010).

Our results and the previous published information suggest that the region around the Trindade and Martim Vaz archipelago may represent a migratory route for humpbacks that visit Brazilian waters. Furthermore, the frequency of groups of whales in this oceanic region during migration may be increasing due to population growth and the reoccupation process on the part of the stock of whales that have been using Brazilian waters after the cessation of whaling activities. This hypothesis has been presented to explain the growing extension of the area in which the occurrence of whales has been reported north of the Abrolhos bank (ROSSISANTOS et al., 2008; ANDRIOLO et al., 2010). Another reasonable explanation for the occurrences of humpbacks presented in this study is the more frequent presence of researchers visiting Trindade Is., which increases the possibility of sightings. We recommend future long-term, systematic studies for the investigation of the habitat use, group composition and behavior pattern of $M$. novaeangliae in the oceanic waters around Trindade Island.

\section{ACKNOWLEDGEMENTS}

The authors were in part sponsored by the Fundação Pro-TAMAR, responsible for the longline boat survey and its expends.

\section{REFERENCES}

ALMEIDA, F. F. M. Ilha de Trindade: Registro de vulcanismo cenozóico no Atlântico Sul. In: SCHOBBENHAUS, C.; CAMPOS, D. A.; QUEIROZ, E. T., WINGE, M.; BERBERT-BORN, M. (Ed.). Sítios Geológicos e Paleontológicos do Brasil. Brasília: DNPM/CPRM - Comissão Brasileira de Sítios Geológicos e Paleobiológicos (SIGEP), 2002. p. 369377.

ANDRIOLO, A.; MARTINS, C. C. A.; ENGEL, M. H.; PIZZORNO, J. L.; MÁS-ROSA, S.; FREITAS, A. C.; MORETE, M. E.; KINAS, P. G. The first aerial survey of humpback whales (Megaptera novaeangliae) to estimate abundance in the breeding ground off Brazil (Breeding Stock A). J. Cetacean Res. Manage., v. 8, p. 307-311, 2006.
ANDRIOLO, A.; ROCHA, J. M.; ZERBINI, A. N.; SIMÕES-LOPES, P. C.; MORENO, I. B.; LUCENA, A.; DANILEWICZ, D.; BASSOI, M. Distribution and relative abundance of large whales in a former whaling ground off eastern South America. Zoologia, v. 27, p. 741-750, 2010.

BEST, P. B. Sightings of right and humpback whales in the South Atlantic from nineteenth century whaling logbooks - a preliminary note. Paper SC/60/012 presented to the IWC Scientific Committee, Santiago, Chile, 2008.

CASSOFF, R. M.; MOORE, K. M.; MCLELLAN, W. A.; BARCO, S. G.; ROTSTEIN, D. S.; MOORE, M. J. Lethal entanglement in baleen whales. Dis. Aquat. Org., v. 96, p. 175-185, 2011.

FREITAS, A. C.; KINAS, P. G.; MARTINS, C. C. A.; ENGEL, M. H. Abundance of humpback whales on the Abrolhos Bank wintering ground, Brazil. J. Cetacean Res. Manage., v. 6, p. 225-230, 2004.

HAUSER, N.; ZERBINI, A. N.; GEYER, Y.; HEIDEJØRGENSEN, M. P.; CLAPHAM, P. J. Movements of satellite-monitored humpback whales, Megaptera novaeangliae, from the Cook Islands. Mar. Mamm. Sci., v. 26, n. 3, p. 679-685, 2010

LODI, L. Ocorrências de baleias-jubarte, Megaptera novaeangliae, no Arquipélago de Fernando de Noronha,incluindo um resumo de registros de capturas no Nordestedo Brasil. Biotemas, v. 7, n. 1-2, p. 116-123, 1994.

MARTINS, C. C. A.; MORETE, M. E.; ENGEL, M. H.; FREITAS, A. C.; SECCHI, E. R.; KINAS, P. G. Aspects of habitat use patterns of humpback whales in the Abrolhos Bank, Brazil, breeding ground. Mem. Queensl. Mus., v. 47, p. 563-570, 2001.

PIZZORNO, J. L. A.; BRITO JR. J. L.; DORNELES, P. R.; AZEVEDO, A. F.; GURGEL, I. M. G. N. Review of strandings and additional information on humpback whales, Megaptera novaeangliae, in Rio de Janeiro, southeastern Brazilian coast (1981-1997). Rep. Int. Whaling Comm., v. 48, p. 443-446, 1998.

ROSSI-SANTOS, M. R.; NETO, E. S.; BARACHO, C. G.; CIPOLOTTI, S. R.; MARCOVALDI, E.; ENGEL, M. H. Occurrence and distribution of humpback whales (Megaptera novaeangliae) on the north coast of the State of Bahia, Brazil, 2000-2006. ICES J. Mar. Sci., v. 65, p. $667-673,2008$.

SECCHI, E. R.; DALLA ROSA, L.; KINAS, P. G.; SANTOS, M. C. O.; ZERBINI, A. N.; BASSOI, M.; MORENO, I. B. Encounter rates of whales around the Antarctic Peninsula with special reference to humpback whales, Megaptera novaeangliae, in the Gerlache Strait: 1997/98 to 1999/2000. Mem. Queensl. Mus., v. 47, p. 571-578, 2001.

SICILIANO, S. Preliminary report of the occurrence and photo-identification of humpback whales in Brazil. Rep. Int. Whaling Comm., v. 45, p. 138-140, 1995.

STONE, G. S.; HAMMER, W. Humpback whales Megaptera novaeangliae and southern right whales Eubalaena australis in the Gerlache Strait, Antarctica. Polar Rec., v. 24 , p. $15-20,1988$.

TOWNSEND, C. H. The distribution of certain whales as shown by logbook records of American whaleships. Zoologica, v. 19, p. 1-50, 1935. (4 charts). 
ZERBINI, A. N.; ANDRIOLO, A.; ROCHA, J. M.; SIMÕES-LOPES, P. C.; PIZZORNO, J. L.; WAITE, J. M.; DEMASTER, D. P.; VANBLARICOM, G. R.

Winter distribution and abundance of humpback whales (Megaptera novaeangliae) off northeastern Brazil. J.

Cetacean Res. Manage., v. 6, p. 101-107, 2004.

ZERBINI, A. N.; ANDRIOLO, A.; DANILEWICZ, D.; HEIDE-JØRGENSEN, M. P.; GALES, N.; CLAPHAM,

P. J. An update on research on migratory routes and feeding destinations of Southwest Atlantic humpback whales. Paper SC/63/SH23 presented to the IWC Scientific Committee, Tromso, Norway, 2011.

(Manuscript received 10 October 2011; revised 03 June 2012; accepted 05 June 2012) 
ERRATA:

BRAZILIAN JOURNAL OF OCEANOGRAPHY, 60(3):381-390, 2012

\begin{abstract}
A SECTION-SAMPLING DESIGN TO ASSESS ZOOPLANKTON DISTRIBUTION IN A HIGHLY COMPLEX HYDROGRAPHIC REGION (SW ATLANTIC OCEAN, $34-41^{\circ} \mathrm{S}$ ): INSIGHTS FOR A NEW TIME SERIES?
\end{abstract}

Na pág. 381 nas linhas de 5 a 10:

Onde se lê:

Georgina Daniela Cepeda*, Rosana Di Mauro, Patricia Martos and Maria Delia Viñas

Instituto Nacional de Investigación y Desarrollo Pesquero (INIDEP)

(Paseo Victoria Ocampo No 1, B7602HSA - Mar del Plata, Argentina)

*Corresponding author: gcepeda@ fiba.org.ar

Leia-se:

Georgina Daniela Cepeda $^{1,2} *$, Rosana Di Mauro ${ }^{3}$, Patricia Martos ${ }^{1,2}$ and Maria Delia Viñas ${ }^{1,3}$

${ }^{1}$ Instituto Nacional de Investigación y Desarrollo Pesquero (INIDEP

(Paseo Victoria Ocampo $\mathrm{N}^{\circ}$ 1, B7602HSA - Mar del Plata, Argentina)

${ }^{2}$ Instituto de Investigaciones Marinas y Costeras (IIMyC)

${ }^{3}$ Department of Oceanography and Coastal Sciences, Louisiana State University (Baton Rouge, LA 70808, USA)

*Corresponding author: gcepeda@inidep.edu.ar; mdvinas@inidep.edu.ar

NOTE

BRAZILIAN JOURNAL OF OCEANOGRAPHY, 60(3):455-459, 2012

SIGHTINGS OF HUMPBACK WHALES ON THE VITÓRIA-TRINDADE CHAIN AND AROUND TRINDADE ISLAND, BRAZIL

Salvatore Siciliano, Jailson F. de Moura, Henrique R. Filgueiras, Paulo P. Rodrigues and Nilamon de Oliveira Leite Jr.

Na pág. 455, coluna direita, linha 8 :

Onde se lê:

Reported 16 sightings of humpback whales off Trindade Is. and in the surrounding area between 1984 and 1994.

Leia-se

Siciliano (S. Siciliano, pers. comm.) reported 16 sightings...

Na pág. 456, coluna direita linhas 15 a 18 :

Onde se lê:

Reports of humpback whales relating to 1984, 1993 and 1994 were the first evidence of the presence of the species off Trindade in recent decades.

Leia-se:

Reports of humpback whales... in recent decades (Siciliano, pers. comm.).

Na pág. 457, legenda da Table 1:

Onde se lê:

The table also shows previously published sightings around Trindade Island provided* and Townsend (1939)\#. Leia-se:

The table also shows previously published sightings around Trindade Island provided by Siciliano (S. Siciliano, unpublished data)* and Townsend (1939)\#. 